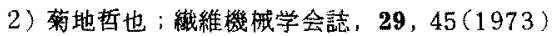

3) ステファニー・ルイス・クオレック(デュポン); 特開昭 $45-36852$

4) トーマス・アーペンパアー，ポール・ウインスロ ップ・モーガン(デニポソ)：特開昭 47-2489

5) K. Tashiro, M. Kobayashi and H. Tadokoro, Macromolecules, 10, 413 (1977)

6) 長谷川隆平, 木本和幸, 茶谷陽三，田所去行，関口 显; 第 23 回高分子討諭会講演要旨集，713(1974)

7) M. G. Northolt, J. J. van Aartsen; J. Polym. Sci., B, 11, 333 (1973): M. G. Northolt; Eur. Polym. J., 10,799 (1974)

8) 菊地哲也；高分子，25，182(1976)
9) V. Frosini, E. Butta; J. Polym. Sci, B, 9, 253 (1971)

$10)$ A. E. Woodward, H. Stefanou; J. Macromol. SciPhys., B9(2), 267 (1974)

11 G.F.L. Ehlers, K.R. Fisch, W.R. Powell; J. Polym. Sci. A-1, 8, $3511(1970)$

12) 田所宏行；緎学誌，31，P-278(1975)

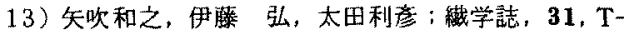

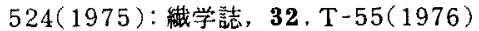

14) K.H. Illers, H. Breuer; Kolloid-Z., 176, 110 (1961); D.G. Legrand, P.F. Erhardt; J. Appl. Polym. Sci. 13, 1707 (1969)

(昭和 52 年 4 月 12 日受理)

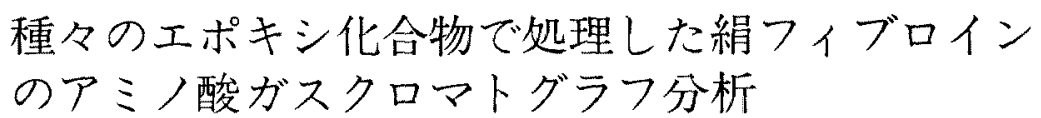

\author{
東京工業大学工学部坂本宗仙・䊗山孝一・中山交孝 \\ 神奈川案工業試験所塩崎英樹 \\ 紻維总分子材料研究所 由中芳雄
}

\title{
GAS-LIQUID CHROMATOGRAPHIC ANALYSIS OF AMINO ACIDS FOR SILK FIBROINS TREATED WITH VARIOUS EPOXIDES
}

\author{
By Munenori Sakamoto*, Koh-Ichi Kajiyama*, Fumitaka Nakayama*, \\ Hideki Shiozaki** and Yoshio Tanaka*** \\ * (Department of Textile and Polymeric Materials, Tokyo Institute of Technology, \\ Meguro-ku, Tokyo Japan.) \\ ** (Industrial Research Institute of Kanagawa, Kanazawa-ku, Yokohama, Japan.) \\ *** (Research Institute of Polymers and Textiles, Kanagawa-ku, Yokohama, Japan.)
}

\begin{abstract}
Amino acid analysis of the chemically modified silk fibroin samples which were obtained by the treatment with glycidol (G), epichlorohydrin (E), glycidyl methacrylate (GMA), methyl glycidyl ether (MGE), ethyl glycidyl ether (EGE), isopropyl glycidyl ether (IPRGE) and allyl glycidyl ether (AGE) in the presence of aqueous neutral salt was made by the gas-liquid chromatographic (GC) method with amino acids being converted to $n$-butyl esters of $\mathrm{N}$, (O)-trifluoroacetyl derivatives and by the conventional ion-exchange chromatographic method with an automated amino acid analyzer. It was found that all the chemically modified silk fibroins yielded G-tyrosine adduct, i.e., O-(2,3-dihydroxypropyl)tyrosine (G-TYR) by acid hydrolysis, indicating that chlorine in E-tyrosine adduct and aliphatic ether linkages in alkyl glycidyl ether-tyrosine adducts were unstable under the hydrolytic conditions.

The GC amino acid analysis revealed that, in addition to G-TYR, the G-treated silk yielded two minor products of unknown structure and the E-treated and the EGE-treated silk samples yielded E-tyrosine adduct and EGE-tyrosine adduct, respectively, when being hydrolyzed. The Kovats retention indices of the epoxidemodified tyrosines were determined on $\mathrm{OV}-17$ and on Dexsil $300 \mathrm{GC}$ and the relationship between the indices and the structure of the tyrosine derivatives was discussed.
\end{abstract}




\section{1. 緒亚}

程埼，田中出住，中珄程水溶液存在下で各種のエポ キシ化合物が䅏フィブロインと反応することを見出し， 絹の重量增加に伴いチロシン(TYR)含有量が大きく減 少するところから、この反応が主としてTYR残基への エポキシ化合物の付加であると推定した。我々は前報 5 , 6) に拈いてプロビレンオキシド(PO)，1,2ーブチレンオ キシド(BO)，フェニルグリシジルェーテル(PGE)执よ びрートリルグリシジルェーテル(TGE)で処理した組つ ィブロインの酸加水分解物について，Gehrkeら”の方法 に準じて揮発性のN(O)ートりフルォロアセチルクーブチ ルエステル(BTFA)誘導体としたのちガスクロマトグラ フ(GC)分析を行い，これらのエポキシト゚の TYR残基 への付加反応に由来する変性了ミ，酸，すなわち，O(2-ヒドロキシプロピル)於ン (PO-TYR)，O-(2 一ヒドロキシブキル)キロシン $(\mathrm{BO}-\mathrm{TYR}), \quad \mathrm{O}-(2-$ 七 トロキシー3ーフェノキシプロピル)チロンメ(PGE-TYR) および○ー(2-ヒドロキシー3-pートリルオキシプロピル) チロシン(TGE-TYR)によると考えら机るピークがク ロマトグラム上に現われることを報告した。本報におい ては，ダリシドール $(\mathrm{G})$; エピクロルヒドリン $(\mathrm{E})$ ， ג タクリル酸グリシジル(GMA)，メチルグリシジルエー テル(MGE)，エチルクリシジルエーテル(EGE)，イン ブロピルダリシジルェーテル(IPRGE)およびアリルグ リシジルエーテル(AGE)で処理した絧につけて同㥞の GC分析を行ったところ，こ机らの酸加水分解物にはい

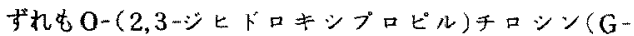
TYR）が含まれていることを見出したので，このことに ついて以下報告する。

\section{2. 実験}

$2.1 \beta-ク$ ロ $-\alpha-$ アラニン

シスチンのメチルエステル塩酸塩 ${ }^{8)}$ と塩素の反応によ

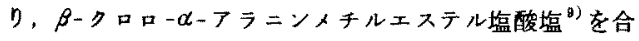
成した。mp, $153 \mathrm{C}$ (交献值 $156 \mathrm{C}$ )。このむのを加水分 解しアンモニア好理することにより， $\beta$ ークロロー ニン ${ }^{10}$ )を得た。 $\mathrm{mp}, 160-170 \mathrm{C}$ (分解)(文献値 160170 C分解)。

\section{2 試料およひ試薬}

絹織物試料は前報”て述べたものを用いた。各種エポ キシ化合物は市販品を減圧蒸留して用いた。その他の試 薬は前報らで述べたものを用いた。

2.3 繯綂物のエポキシ化合物処理

前報に準じて行った。処理条件は表 2 に示す。 $2.4 P$ ミノ酸のGC 分析
酸加水分解，BTFA誘導体化ならびにOV-17 拉よび Dexsil $300 \mathrm{GC}$ カラムを用いる GC 分析は前報 ${ }^{5)}$ と同 様にして可った。

2.5 アミノ酸分析計による分析

日本電子製，JLC $-5 \mathrm{AH}$ 自動 $7 、$ 酸分析計を用い 禋準の条件で分析した。

\section{3. 結果亡考察}

\subsection{G、EおよびGMA処理絹についての定性} 分析

末処理綟， G 処理綟，E姏理綟扝よびGMA処理絧の 酸加水分解物のBTFA誘導体について，OV-17 执よび Dexsil $300 \mathrm{GC}$ 夜相として用い，昇温法で得たがス クロマトダラムを図 1 および 2 に示した。G処理編のク ロマトグラムには未処理綟のクロマトグラムに見られな い3つの新しいピークが見出された。外部標準として加 えたステフリン酸 $n$ ーブチル(BS)のビークの前に現われ る第一のピークの保持指標 "'は, OV-17に対して 2337 , Dexsil 300 GCに対して2329である。またBSピーク の後に現われる第二のピークの保持指標は，OV-17に 対し2707,Dexsil 300 GCに対し2705，また第三の

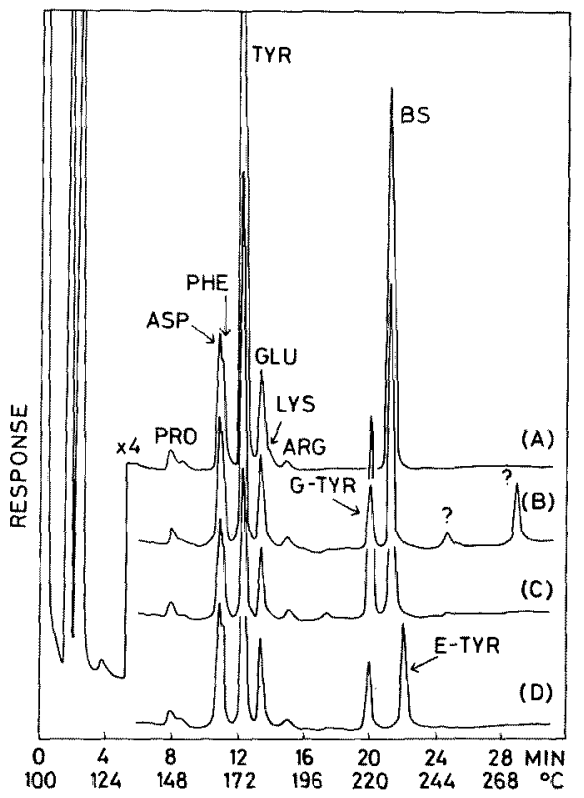

Fig. 1 Gas chromatograms of the hydrolysates (with or without BS) of (A), untreated silk; (B), glycidoltreated silk; (C), glycidyl methacrylate-treated silk; and (D), epichlorohydrin-treated silk on OV-17. 


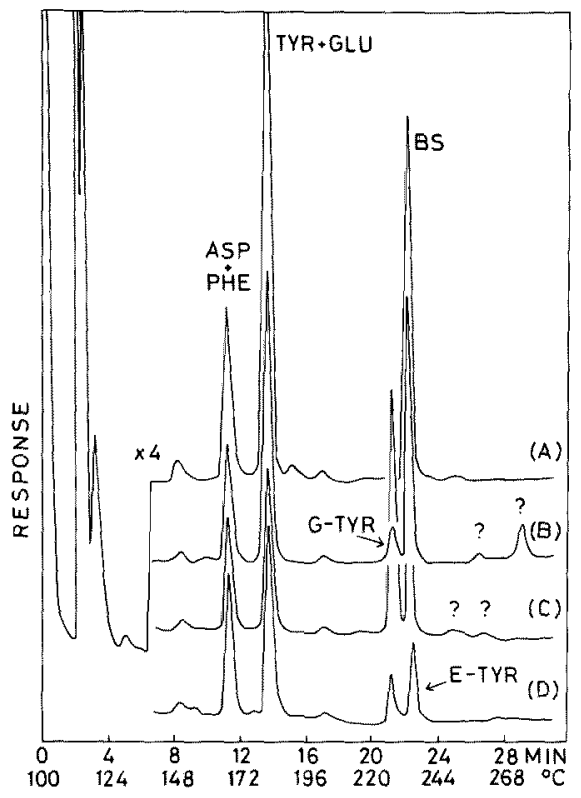

Fig. 2 Gas chromatograms of the hydrolysates (with or without BS) of (A), untreated silk; (B), glycidoltreated silk; (C), glycidyl methacrylate-treated silk; and (D), epichlorohydrin-treated silk on Dexsil $300 \mathrm{GC}$.

ピークの保持指標は，OV-17 に対し3079，Dexsil 300 GCに対し2931 であった。GMA処理絧のクロマトグラ ムには，G処理編のクロマトグラムの第一の知ビーク と同じ位置に新たなピークが認められ，これ以上に顕著 な末知ピークは認められない。これに対し，E処理絹の クロマトグラムムには二つの新しいピークが認められ，第一 の未知ピークは， G 処理綟のクロマトグラムの第一の未知 ピークと同じ位置にある。第二の未知ピークの保持指標 は，OV-17 に対して2539, Dexsil 300 GC に対して 2408 であり，この位置は，G処理網の他の未知ビーク のいずれとも一致しない。図 3 には、これらェポキシ化 合物で処理した綟の酸加水分解物をフミ，酸分析計にか けて得られるクロマトグラムの一部を示した。G，GMA およびE 処理編に共通した未知ピークがTYRのピーク

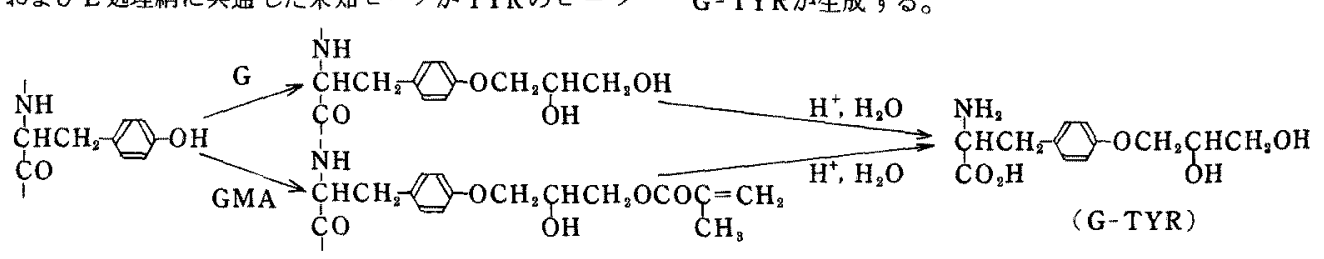

“通常の分析時間よりもずっと長時間緩衝萑を流し続けたところ，第二の未知ピークが現われた。

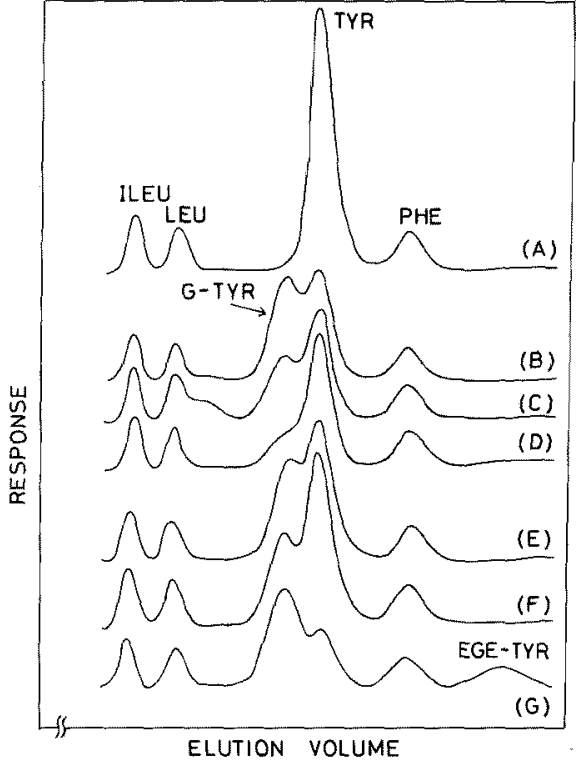

Fig. 3 Automatic ion-exchange chromatography of the hydrolysates of (A), untreated silk; (B), glycidyl methacrylate-treated silk; (C), glycidol-treated silk; (D), epichlorohydrin-treated silk; (E), allyl glycidyl ether-treated silk; (F), ethyl glycidyl ether-treated silk; and $(G)$, isopropyl glycidyl ether-treated silk.

の前に認められる。G-処理綟の場合はさらにロイシン (LEU)のピークの後に未知ピークが認められるが，第 三の末知ピークは見出されなかった。E処理絧についても 第二の未知ピークは見出されなかっだ。GC分析で見出 されるアミノ酸のビークが，フミ，酸分析計による分析 で見出されない例性にも報告"文されている。

以上の結果より，G，GMAおよび $\mathrm{E}$ 処理綟の酸加水 分解物中には其通の变性アミ，酸が含ま机ていることは 明らかであり，その構造はOー (2,3-シヒドロキシプロピ 心)チロシン(G-TYR)であると考えられる。紜フィブ ロイン中のG 付加 TYR 残基の酸加水分解により G-TYR が生成することは当然である。GMA付加TYR残基の酸 加水分解では側鎖のエステル結合の加木分解もおこり， G-TYRが生成する。 
これに対し，E処理絹からもG-TYRが生成するのは予想外であったが，E付加 TYR残基を酸加水分解する際， 一部の塩素原子が水酸基に圆換されるむのと考えられる。したがって すなわち○-(2-ヒドロキシー3ータロロプロビル)チロシン(E-TYR)であるらと推定される。

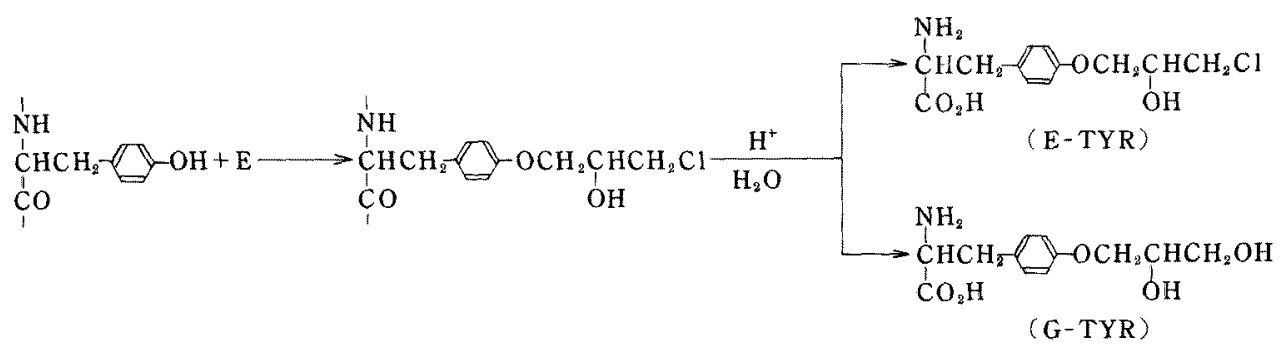

この推定が妥当といえるか否かを GC分析に扔ける保持指標をもとに考 察した。保持指標に及淁す塩素原子の

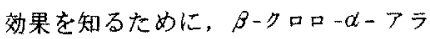
ニン(CLALA)を合成し，その保持指 票を求めアランン( $\mathrm{ALA}) の$ 保持指標 と此較したところ，アラニンの炭素 に塩素原子が結合することにより， OV-17に対し175, Dexsil $300 \mathrm{GC}$

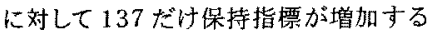
ことがわかった。そこで $\mathrm{E}$ 処理絹の第 二の末知ピークの保持指標と PO-TYR の保持指標の差を調べたところ，OV-

17 に対し205. Dexsil 300 GCに対して165であり， これは前述のCLALAについて求めた塩素原子の効果に ほぼ一致している。したがってこの未知ピーク物筫が， PO-TYRに塩素原子が結合した形のEーTYRであるこ とは充分考えられる。ついでに，G-TYRの保持指權に ついて考察してみる。セリン(SER)とALAの保持指標 の差，すなわち，ALAの本菜原子を水酸基( BTFA誘 導体化して CF ${ }_{3} \mathrm{COO}$ 基になっている)でおきかえる効果 は, OV-17に対して56, Dexsil 300 GCK対し82で ある。-TYRとPO-TYRの構造には同様に水酸基一 つの差があるが，その保持指標の差は OV-17に対し 43 ， Dexsil $300 \mathrm{GCK}$ 对し86であり，これらの值は前述の SERとALAの保持指標の差にほぼ等しい。したがって， G，GMAおよびE処理綟に共通するピークがG-TYR によるものであると考えたことは妥当であると考光られ る。

以上て述バてもたアミノ酸の保持指摽を表 1 にまとめ て示した。な扔，E処理絹の酸加水分解物のBTF A 誘導 体についてGC-MS分析を行い，上述の未知ピークがて れぞれ G-TYR拉よびE-TYRによるものであることを 確諗し，第 5 回国際羊毛絨維研究会議で簡単に報告した
Table 1 Retention indices of BTFA amino acids.

\begin{tabular}{lcccc}
\hline \multirow{2}{*}{ Amino acid } & \multicolumn{2}{c}{ Retention indices } & Difference & Lit \\
& ov-17 & Dexsil 300 GC & $(\Delta I)$ & \\
\hline Alanine & 1261 & 1218 & 43 & 12 \\
$\beta$-Chloro- $\alpha$-alanine & 1436 & 1355 & 81 & This work \\
Serine & 1317 & 1300 & 17 & 5 \\
PO-TYR & 2334 & 2243 & 46 & 5 \\
E-TYR & 2539 & 2408 & 131 & This work \\
G-TYR & 2377 & 2329 & 48 & This work \\
EGE-TYR & 2519 & 2424 & 95 & This work \\
\hline
\end{tabular}

Abbreviation used: PO-TYR, O-(2-hydroxypropyl)tyrosine; E-TYR, O-(2-hydroxy-3-chloropropyl) tyrosine; G-TYR, O-(2,3-dihydroxypropyl)tyrosine; EGE-TYR, O-(2-hydroxy-3-ethoxypropyl)tyrosine; and BTFA amino acids, $\mathrm{N}$-trifluoroacetyl $n$-butyl esters.

がは)，その詳細については他の場合とあわせ，別の機会 に報告する予定である。

最後に，G処理䅌のガスクロマトグラムに誌められる 残りの二つの未知ピークについては，チロシン残基に対 するGのシ付加体や卜り付加体に由来する变性了ミノ酸 である可能性が考えられるが，保持指標の検討だけで結 論を下すことは出来ないので，これについては後日， GC-MS分析により検討する予定である。

\section{2 アルキルグリシジルエーテル処理絹につい ての定性分析}

MGE，EGE，IPRGEおよびAGE処理絀について同 様にGC分析を行って得られるクロマトグラム在 4 招 よび5に示した。これらいずれの試料のクロマトグラム にもG-TYRのピークが琶められた。このことはアミノ 酸分析計による分析でむ確められた。AGE処理縜の昜 合を四3に示した。TYR残基へのこれらアルキルグリ シジルエーテル付加体のメーテル結合は、フリールグリ シジエーテル村加体の場合 ${ }^{8}$ とことなり，酸加水分解 時に容易に切断されることを意味する結果である。

EGE処理絧の量合はかなり影著な第二の未知ピークが 認められ，その保持指標はOV-17に対し2519, Dexsil 


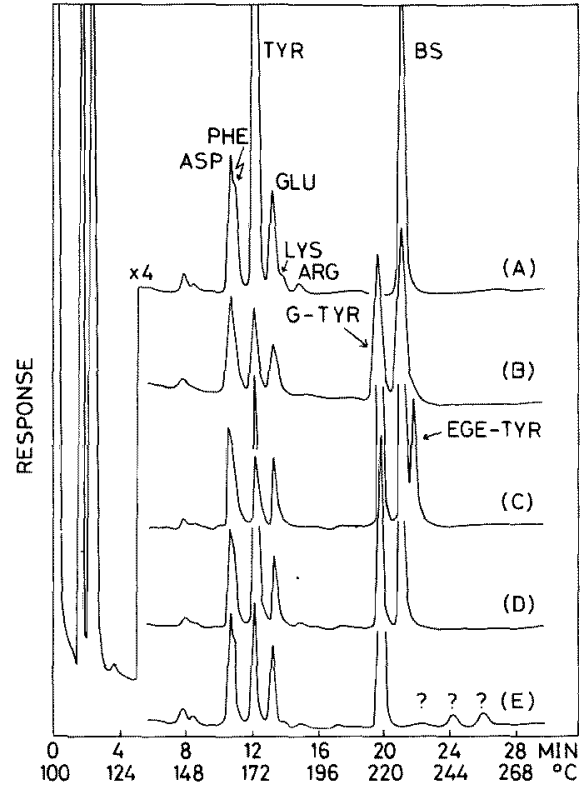

Fig. 4 Gas chromatograms of the hydrolysates (with or without BS) of (A), untreated silk; (B), methyl glycidyl ether-treated silk; (C), ethyl glycidyl ether-treated silk; (D), isopropyl glycidyl ethertreated silk; and (E), allyl glycidyl ether-treated silk on OV-17.

300 GCに対し 2424 であり，E-TYRの值に近いが， この量合 E-TYRが生成することは考えにくく，むしろ EGEのTYR 付加体すなわら O-(2-ヒドロキシー3ーエト キシプロピル)チロンン(EGE-TYR)であると考えた方 が妥当である。この未知物質が E-TYRでないというこ とを確認するために，EGE処理絹の酸加水分解物をつ ミノ酸分析計にかけてみたところ，G-TYRのピークが

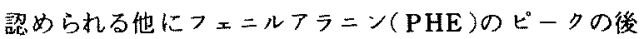
に第二の未知ビークが認められだが，この位置に $\mathrm{E}$ 処理 粗の酸加水分解物ではピークは認められない(F ig. 3 )。 したがってEGE処理組についてのガスクロマトグラム に認められる第二の米知ビークはE-TYRによるもので はないと判断される。EGE-TYRの構造はPO-TYRの 本菜原子一つをエトキシ $\left(\mathrm{C}_{2} \mathrm{H}_{6} \mathrm{O}\right)$ 基で置換したものに相 当する。EGE-TYRと考えられる末知ピークの保持指 骠とPO-TYRの保持指標の差は，OV-17に対し185， Dexsil $300 \mathrm{GCK}$ 対し181であり，この值はエトキシ 基による值としては小さすぎるきらいがある。この点が 飱問であるが，その後のGC-MS分析によりこの未知ピ *エリ鲁をEGE処理した場合も同様な結果が得られて いるい)。

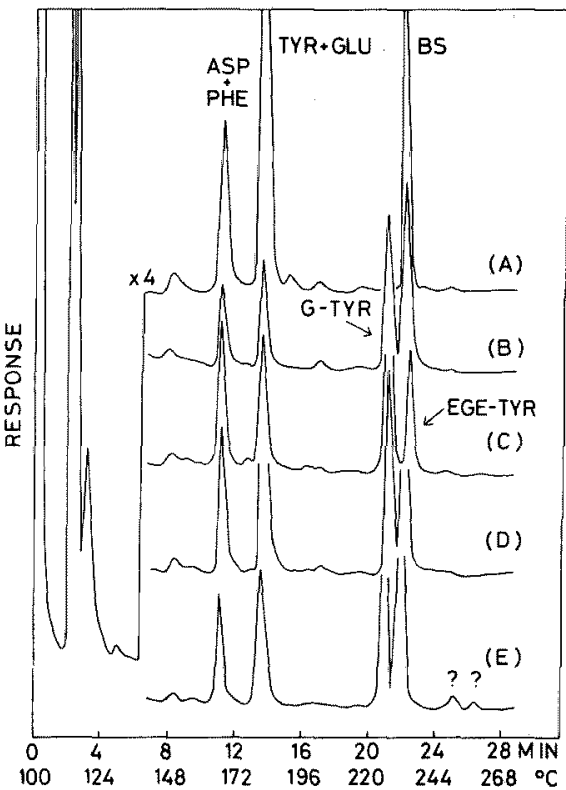

Fig. 5 Gas chromatograms of the hydrolysates (with or without $B S)$ of (A), untreated silk; (B), methyl glycidyl ether-treated silk; (C), ethyl glycidyl ether-treated silk; (D), isopropyl glycidyl ethertreated silk; and (E), allyl glycidyl ether-treated silk on Dexsil 300 GC.

ークがEGE-TYRであることを確認した。このことに ついては別の機会に報告する予定である。

AGE 処理䅌のガスクロマトグラムにはG-TYRのピ 一クの他に小さないくつかの未知ピークが認められる。 これらの未知ピークについては検討しなかった。

\section{3 G-TYRの定量分析}

G-TYRのGCによる定量分析に必要な相対千儿感度 は前報 ${ }^{6,8)}$ と同様にECN法により推定した。 $-\mathrm{CO}_{2}-$ ， - $\mathrm{NHCOCF}_{3}$ 抺よびー- $\mathrm{COCF}_{3}$ 基の $\mathrm{ECN}$ をそれぞれ $-0.5^{12)},-0.7^{12)}$ および $0.4^{(6)}$ とし，G-TYRについて $\Sigma \mathrm{ECN}$ を求めると 13.6 となる。グルタミン酸(GLU)の $\Sigma$ ECNは 9.3 となるのでG-TYRのGLUに対する相対 モル感度は1.46となる。亭際にはさらにBSに対する相 对モ心惑度に换算しなおし，BSを外部標哖として定量 分析を行う。

一部の試料についてはフミノ酸分析計を用いた定量分 析を同時に行った。G-TYRの発色係数はPHEの值に 等しいと仮定し、この值を用いて定量分析を行った。い ずれの分析法の場合も，アミ，酸分析值はエポキシ処理 による重量堌加を考虑して補正し，未処理程 $1 \mathrm{~g}$ 当りの モル数で示した。得られた結果を表 2 に示す。 
Table 2 Amino acid analysis of silk fabrics treated with various epoxides. ${ }^{a}$

\begin{tabular}{|c|c|c|c|c|c|c|c|c|}
\hline \multirow{3}{*}{$\frac{\text { Epoxide }}{\text { Untreated }}$} & \multirow{2}{*}{ Reaction conditions $^{\mathrm{b}}$} & \multicolumn{2}{|c|}{ Add on } & \multirow{2}{*}{$\begin{array}{l}\text { Hydrolysis } \\
\text { time, hr }\end{array}$} & \multirow{2}{*}{ Method $^{c}$} & \multicolumn{3}{|c|}{ Amino acids, $\mu$ moles/g } \\
\hline & & & & & & TYR & $G-1 Y R$ & 1YKTERI \\
\hline & & & & 8 & $\mathrm{GC}$ & 657 & & 657 \\
\hline & & & & & $\mathrm{LC}$ & 631 & & 631 \\
\hline \multirow[t]{2}{*}{ G } & Ethanol $/ 15 / 68 / 6$ & 6.08 & 821 & 24 & GC & 462 & 57 & 519 \\
\hline & & & & & $\mathrm{LC}$ & 631 & 70 & 482 \\
\hline \multirow[t]{3}{*}{ GMA } & Toluene/15/75/6 & 4.85 & 341 & 8 & $\mathrm{GC}$ & 232 & 301 & 533 \\
\hline & & & & 24 & $\mathrm{GC}$ & 223 & 278 & 501 \\
\hline & & & & & LC & 259 & 280 & 539 \\
\hline \multirow[t]{2}{*}{$\mathrm{E}$} & Ethanol $/ 15 / 75 / 3$ & 3.03 & 327 & 24 & $\mathrm{GC}$ & 355 & 58 & 413 \\
\hline & & & & & LC & 323 & 63 & 386 \\
\hline MGE & Ethanol $/ 20 / 68 / 6$ & 6.60 & 750 & 24 & GC & 252 & 280 & 532 \\
\hline \multirow[t]{2}{*}{$\mathrm{EGE}$} & Ethanol $/ 20 / 75 / 6$ & 7.78 & 762 & 24 & $\mathrm{GC}$ & 116 & 296 & 412 \\
\hline & & & & & LC & 125 & 327 & 452 \\
\hline \multirow[t]{2}{*}{ IPRGE } & Ethanol $/ 20 / 75 / 6$ & 5.39 & 464 & 24 & GC & 364 & 192 & 556 \\
\hline & & & & & LC & 375 & 203 & 578 \\
\hline \multirow[t]{3}{*}{ AGE } & Ethanol/15/68/6 & 6.53 & 572 & 8 & GC & 168 & 267 & 435 \\
\hline & & & & 24 & GC & 144 & 257 & 401 \\
\hline & & & & & LC & 177 & 280 & 457 \\
\hline
\end{tabular}

${ }^{a}$ Silk fabrics were padded with $1 \mathrm{~N} \mathrm{Na}_{2} \mathrm{~S}_{2} \mathrm{O}_{3}$ to about $100 \%$ pick up and treated with an epoxide solution as given below. Hÿdrolysis of the sample was made with constant-boiling $\mathrm{HCl}$ in a sealed tube at $100^{\circ} \mathrm{C}$.

biven in the order: solvent/concentration in $v / v \% /$ reaction temperature in ${ }^{\circ} \mathrm{C} /$ reaction time in $\mathrm{h}$.

- $\mathrm{GC}$, gas-liquid chromatography; LC, with an automatic amino acid analyzer.

GCで推定されたG-TYRの量を，フミノ酸分析計 (LC法)で推定された G-TYRの值に対しプロットした のが図6である。各点は原点を通る直線上にあり，両者 の值はほぼ一致することが示されている。TYRとGTYR含有量の和(表 2)は，いずれの試料でも末好理の TYR含有量より小さな値となっている。G処理絹の場合， 重量增加率より予想される G 付加量性，生成するG-TYR の量よりきわめて大きく、また反応による TYR 瑊少量 にくらべてもきわめて大きい。この場合，GMAやEの 昜合の上うに TYR 残基への単純な付加反心のみではそ の大きな付着量を説明できないことがわかる。 MGE， EGEおよび IPRGE処理の場合も，重量增加率より求 められる付加量住 TYR 减少量よりもかなり大きい。

綟中には TYRよりも多量のSER牫基が含まれている。 エボキシト奶理䋖のアミ/酸分析の結果 よるSERの減少量は小さい。いまSER残基に土ポキ シ化合物が付加した構造を考えると，シアルキルエー テル型の結合が生ずる筈であるが，本研究の結果から考 えるとこの結合は塩酸加木分解時に切断される可能性 がある。むしもその結果，SERが生成するむのとす れば，みかけ上SER残基は反応していないだけであっ て，実蔡にはかなりエポキシ化合物の付加がおきている ことになる。この点は今後に残された興味ある問題点で ある。

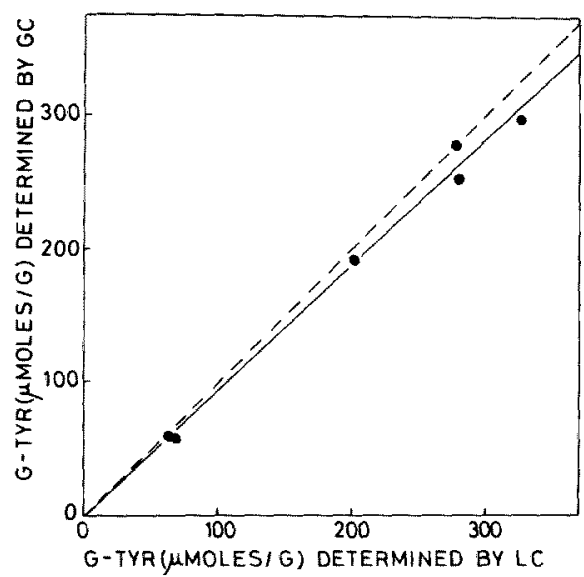

Fig. 6 Comparison of the G-TYR contents, in silk samples treated with various epoxides (see Table 2), estimated by gas chromatography (GC) and by automatic ion exchange chromatography (LC). 


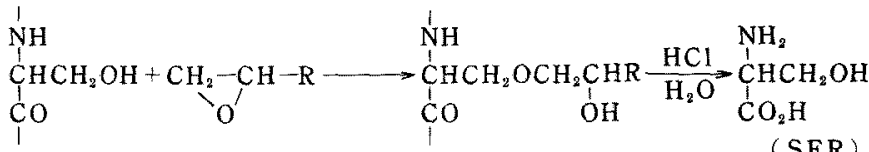

\section{4. 結論}

G, GMA， E，MGE，EGE，IPRGE拈よびAGEで 処理した絹フィブロインの酸加水分解物起BTFA誘導体 にしたのちGC分析したところ，いお゙れの試料にものーく， 3ージヒドロキシプロピル)チロシン(G-TYR)が含まれて いることがわかった。またこのアミノ酸は，アミ，酸分 析計ではTYRのすぐ前に溶出する。G処理綟フィブロ インからG-TYRが生成するのはGの付加したTYR牫 基の加水分解で説明される。GMA処理綟の場合は, GMAの付加したTYR残基の加水分解処理でペプチド 結合の他にエステル結合も加水分解を受けるため，E処 理絧の場合は Eの付加したTYR残基の加水分解処理中, 一部の塩素原子が我酸基で置换されるため，末たアル中 ルダリシジニーテル処理絹の場合は，フルキルグリシ ジメーテルの付加LたTYR残基の加水分解処理でエ 一テル結合が切断されるためいずれも G-TYRが生成す る。E扔よびEGE処理綟の場合はここ机らがTYRの 本酸基に付加した形のアミ，酸(E-TYR抢よびEGE TYR）と考えられるピークががスクロマトクラム上に認 められた。また G処理綟の蝪合，G-TYRの他に二つの 頊著な未知ピークが認められた。

付 記：本研究の一部に協力して頂いた佐藤康正氏扔 よび山川一三男氏に感謝の意安表します。

\section{文献}

1) H. Shiozaki, Y. Tanaka; J. Polymer $S_{c i}$, B, 7, 325 (1969)

2) Y. Tanaka, H. Shiozaki; Makromol Chem., 129 , 12 (1969)

3) H. Shiozaki, Y. Tanaka; Makromol. Chem., 143, 25 (1971)

4) H. Shiozaki, Y. Tanaka; Makromol. Chem., 152, 217 (1972)

5) 坂本宗仙，梶山孝一，塩崎英樹，田中芳雄；戴学誌， 31. T-158(1975)

6) 坂本宗仙，儤山孝一，塩畸英樹，田中芳雄；緎学誌， 32, T-335(1976)

7) C. W. Gehrke, D. Roach, R. W. Zumwalt, D. L. Stalling, L. L. Wall; Quantitative Gas-Liquid Chromatography of Amino Acids in Proteins and Biological Substances, Analytical Laboratories Inc., Columbia, Missouri, U.S.A. (1968)

8) R. G. Webb, M. W. Haskell, C. H. Stammer; J. Org. Chem., 34, 576 (1969)

9) E. Fischer, K. Raske; Ber., 93, 782 (1960)

10) H. Baganz, G. Dransch; Ber, 40, 3717 (1907)

11) E. Kováts; Helv. Chim. Acta., 41, 1915 (1958), Z. Anal. Chem., 181, 351 (1961)

12) M. Sakamoto, K.-I. Kajiyama, H. Tonami; $J$. Chromatogr., 94, 189 (1974)

13) M. Sakamoto, K.-I. Kajiyama, Y. Sato, F. Nakayama; Proc. 5th Internat. Wool Text. Res. Conf., Aachen, 1975, Vol. V, 339 (1976)

14) Y. Tanaka, H. Shiozaki; J. Polymer Sci, Polymer Chem. Ed. 12, 2741 (1974)

15) A. Islam, A. Darbre; J. Chromatogr., 71, 223 (1972) 